\title{
Micromonospora eburnea sp. nov., isolated from a Thai peat swamp forest
}

\author{
Chitti Thawai, ${ }^{1,3}$ Somboon Tanasupawat, ${ }^{1}$ Takashi Itoh, $^{3}$ \\ Khanit Suwanborirux, ${ }^{2}$ Ken-ichiro Suzuki ${ }^{4}$ and Takuji Kudo ${ }^{3}$ \\ 1,2Departments of Microbiology ${ }^{1}$ and Pharmacognosy ${ }^{2}$, Faculty of Pharmaceutical Sciences, \\ Chulalongkorn University, Bangkok 10330, Thailand \\ 3Japan Collection of Microorganisms, RIKEN BioResource Center, Wako, Saitama 351-0198, \\ Japan \\ ${ }^{4}$ NITE Biological Resource Center, National Institute of Technology and Evaluation, Kisarazu, \\ Chiba 292-0818, Japan
}

Correspondence

Somboon Tanasupawat

Somboon.T@Chula.ac.th

\begin{abstract}
Two actinomycete strains, LK2-10 ${ }^{\top}$ and LK2-5, which produced single, non-motile spores, were isolated from peat swamp forest soil in Yala Province, Thailand. A polyphasic study was carried out to establish the taxonomic position of these strains. Morphological and chemotaxonomic characteristics of these strains coincided with those of the genus Micromonospora.

Phylogenetic analysis using 16S rRNA gene sequences also indicated that these strains should be classified in the genus Micromonospora and clearly separated from their closest relative, Micromonospora nigra DSM $43818^{\top}$. Furthermore, a combination of DNA-DNA hybridization results and physiological and biochemical properties indicated that these strains were distinguished from all recognized Micromonospora species. These strains therefore represent a novel species, for which the name Micromonospora eburnea sp. nov. is proposed. The type strain is LK2-10 $0^{\top}\left(=\mathrm{JCM} 12345^{\top}=\mathrm{PCU} 238^{\top}=\mathrm{DSM} 44814^{\top}=\operatorname{TISTR} 1531^{\top}\right)$.
\end{abstract}

The genus Micromonospora was first described by Ørskov (1923) for actinomycete strains that produce spores singly borne on sporophores branched from substrate hyphae. Skerman et al. (1980) listed 12 species and seven subspecies as members of the genus Micromonospora; subsequently, Micromonospora olivasterospora (Kawamoto et al., 1983), Micromonospora rosaria (Horan \& Brodsky, 1986) and Micromonospora chersina (Tomita et al., 1992) have been recognized as novel species. Lee et al. (1999) transferred Catellatospora matsumotoense to the genus Micromonospora as Micromonospora matsumotoense on the basis of $16 \mathrm{~S}$ rRNA gene sequence analysis. The genus was well defined on both a chemotaxonomic and a phylogenetic basis (Kroppenstedt, 1985; Kawamoto, 1989; Koch et al., 1996a, b; Lee et al., 1999) as well as on morphological grounds. Reclassification of Micromonospora species was carried out by Kasai et al. (2000) on the based of gyrB gene sequence analyses and DNA-DNA hybridization experiments. Consequently, the genus Micromonospora is

Published online ahead of print on 17 September 2004 as DOI 10.1099/ijs.0.63217-0.

Abbreviation: $A_{2} p m$, diaminopimelic acid.

The GenBank/EMBL/DDBJ accession numbers for the 16S rRNA gene sequences of strains $L K 2-10^{\top}$ and LK2-5 are AB107231 and AB159778. considered to accommodate 15 species: Micromonospora aurantiaca, Micromonospora carbonacea, Micromonospora chalcea, M. chersina, Micromonospora coerulea, Micromonospora echinospora, Micromonospora gallica, Micromonospora halophytica, Micromonospora inositola, M. matsumotoense, Micromonospora nigra, M. olivasterospora, Micromonospora pallida, Micromonospora purpureochromogenes and $M$. rosaria. According to Kawamoto (1989), the type strain (NCTC $4582^{\mathrm{T}}$ ) of M. gallica is no longer available.

During investigation of novel actinomycetes from peat swamp forest soil in southern Thailand, we isolated two strains, LK2-10 ${ }^{\mathrm{T}}$ and LK2-5, that showed typical morphological characteristics of the genus Micromonospora but with an unusual colony colour for this genus. Here we report on the taxonomic characterization and classification of these isolates and propose a novel species, Micromonospora eburnea sp. nov., for the strains.

Strains LK2-10 ${ }^{\mathrm{T}}$ and LK2-5 were isolated from soil samples collected from peat swamp forest at Lankwai in Yala Province, Thailand. Samples were taken from the top peat layer (surface of soil). First, $0.5 \mathrm{~g}$ soil was suspended in $4.5 \mathrm{ml}$ sterile distilled water, and the suspension was treated using a wet-heat technique $\left(70{ }^{\circ} \mathrm{C}\right.$ for $\left.15 \mathrm{~min}\right)$. Next, $0.5 \mathrm{ml}$ of this suspension was transferred to another $4.5 \mathrm{ml}$ sterile distilled water and this step was repeated to 
set up a ten-fold dilution series to $10^{-3}$. At the final dilution step, aliquots of $100 \mu \mathrm{l}$ were spread onto starch-casein nitrate agar $(\mathrm{pH} 7 \cdot 2)$ supplemented with $37 \mu \mathrm{g}$ novobiocin $\mathrm{ml}^{-1}$ and $223 \mu \mathrm{g}$ mycostatin $\mathrm{ml}^{-1}$. After 21 days of aerobic incubation at $30^{\circ} \mathrm{C}$, growth of strains LK2 $-10^{\mathrm{T}}$ and LK2-5 was indicated by yellowish white colonies. The colonies of these strains were transferred onto yeast extract-malt extract agar (ISP2 medium).

Morphological properties of strains LK2-10 ${ }^{\mathrm{T}}$ and LK2-5 grown on ISP2 medium were observed by light and scanning electron microscopy (model JSM-5410 LV; JEOL). Samples for scanning electron microscopy were prepared by cutting a block from an agar plate and then fixing it in $1 \% \mathrm{OsO}_{4}$ in $0 \cdot 1 \mathrm{M}$ phosphate buffer $(\mathrm{pH} 7 \cdot 2)$ at room temperature for $4 \mathrm{~h}$. The samples were dehydrated in a graded series of ethanol and then were dried with a criticalpoint dryer (model Samdri-780, Balzers CPD 020). The samples were placed onto a stub bearing adhesive and spatter-coated with gold under vacuum.

Phenotypic properties were examined by using several standard methods; culture characteristics were tested using 14-day cultures grown at $30^{\circ} \mathrm{C}$ on various agar media (Table 1). The Jacal Colour Card L2200 (Japan Colour Research Institute) was used for determining colour designations and names. Decomposition of various compounds was examined using the basal medium recommended by Gordon et al. (1974). Temperature and $\mathrm{NaCl}$ tolerance were determined on ISP2 medium. Carbon source utilization was tested using ISP9 medium (Shirling \& Gottlieb, 1966) supplemented with a final concentration of $1 \%$ of the tested carbon sources and $0.05 \%$ Casamino acid. Gelatin liquefaction, peptonization of milk, nitrite production, cellulose decomposition and starch hydrolysis were determined by cultivation on various media as described by Arai (1975) and Williams \& Cross (1971). Melanin and hydrogen sulphide production were examined on slants of tyrosine agar and peptone iron agar supplemented with $0 \cdot 1 \%(\mathrm{w} / \mathrm{v})$ yeast extract, respectively.

Freeze-dried cells used for chemotaxonomic analyses were obtained from cultures grown in yeast extract-malt extract broth (containing $0.4 \%$ glucose, $0.4 \%$ yeast extract and $1 \%$ malt extract; $\mathrm{pH} 7 \cdot 3$ ) on a rotary shaker at $30^{\circ} \mathrm{C}$. Cell wall peptidoglycan was prepared and hydrolysed by the methods of Kawamoto et al. (1981), and the amino acid composition was analysed with an automatic amino acid analyser. The isomers of diaminopimelic acid $\left(\mathrm{A}_{2} \mathrm{pm}\right)$ in cell walls were determined by the method of Staneck \& Roberts (1974). The acyl group of muramic acid in peptidoglycan was determined by the method of Uchida \& Aida (1984). The reducing sugars from whole cell hydrolysates were analysed by the HPLC method of Mikami \& Ishida (1983). Phospholipids in cells were extracted and analysed by the method of Minnikin et al. (1984). Fatty acid methyl ester analysis was performed by GLC according to the instructions of the Microbial Identification System (MIDI) (Sasser, 1990; Kämpfer \& Kroppenstedt, 1996). Isoprenoid quinones were extracted by the method of Collins et al. (1977) and were analysed by HPLC equipped with a Cosmosil $5 \mathrm{C}_{18}$ column $(4 \cdot 6 \times 150 \mathrm{~mm}$; Nacalai Tesque). The elution solvent was a mixture of methanol and 2-propanol $(2: 1, \mathrm{v} / \mathrm{v})$.

Chromosomal DNA was isolated from cells grown in ISP2 broth according to the method of Tamaoka (1994). The $\mathrm{G}+\mathrm{C}$ content of the DNA was determined using the HPLC method of Tamaoka \& Komagata (1984). An equimolar mixture of nucleotides for analysis of DNA base composition (Yamasa Shoyu) was used as the quantitative standard. DNA-DNA relatedness was measured fluorometrically using the microplate hybridization method devised by Ezaki et al. (1989). Hybridization was carried out at $55^{\circ} \mathrm{C}$ for $2 \mathrm{~h}$.

Genomic DNA extraction, PCR-mediated amplification of the $16 \mathrm{~S}$ rRNA gene and sequencing of the PCR products

Table 1. Culture characteristics of strains $L K 2-10^{\top}$ and LK2-5

\begin{tabular}{|c|c|c|c|c|c|c|}
\hline \multirow[t]{2}{*}{ Medium } & \multicolumn{3}{|c|}{ LK2-10 ${ }^{\mathrm{T}}$} & \multicolumn{3}{|c|}{ LK2-5 } \\
\hline & Growth & $\begin{array}{l}\text { Colour of } \\
\text { colony }\end{array}$ & $\begin{array}{l}\text { Soluble } \\
\text { pigment }\end{array}$ & Growth & $\begin{array}{c}\text { Colour of } \\
\text { colony }\end{array}$ & $\begin{array}{l}\text { Soluble } \\
\text { pigment }\end{array}$ \\
\hline Yeast extract-malt extract agar (ISP2 medium) & Good & Greyish black & Pale yellow & Abundant & Greyish black & Pale yellow \\
\hline Oatmeal agar (ISP3 medium) & Abundant & Dull orange & Pale yellow & Abundant & Dull orange & Pale yellow \\
\hline Inorganic salts-starch agar (ISP4 medium) & Poor & Colourless & - & Poor & Colourless & - \\
\hline Glycerol-asparagine agar (ISP5 medium) & Poor & Yellowish white & - & Poor & Yellowish white & - \\
\hline Peptone-yeast extract iron agar (ISP6 medium) & Good & $\begin{array}{l}\text { Dark yellowish } \\
\text { brown }\end{array}$ & - & Good & Greyish black & - \\
\hline Tyrosine agar (ISP7 medium) & Poor & Yellowish white & - & Moderate & Yellowish white & - \\
\hline Glucose-asparagine agar & Poor & Yellowish white & - & Moderate & Yellowish white & - \\
\hline Czapek's agar & Poor & Yellowish white & - & Moderate & Yellowish white & - \\
\hline Nutrient agar & Moderate & $\begin{array}{l}\text { Dark yellowish } \\
\text { brown }\end{array}$ & Pale yellow & Good & $\begin{array}{l}\text { Dark yellowish } \\
\text { brown }\end{array}$ & Pale yellow \\
\hline
\end{tabular}


were carried out as described by Nakajima et al. (1999). The 16S rRNA gene sequence was multiply aligned with selected sequences obtained from the GenBank/EMBL/ DDBJ databases by using CLUSTAL W version 1.81. Alignment was manually verified and adjusted prior to the construction of a phylogenetic tree. The phylogenetic tree was constructed using the neighbour-joining (Saitou \& Nei, 1987) and maximum-parsimony methods (Kluge \& Farris, 1969) in the MEGA program version 2.1. Confidence values of branches of the phylogenetic tree were determined using bootstrap analyses (Felsenstein, 1985) based on 1000 resamplings. 16S rRNA gene sequence similarities among closely related species were calculated manually after pairwise alignments obtained using the CLUSTAL X program (Thompson et al., 1997). Gaps and ambiguous nucleotides were eliminated from the calculations.

The morphological and chemical properties of strains LK2$10^{\mathrm{T}}$ and LK2-5 are consistent with their classification in the genus Micromonospora (Kawamoto, 1989). Strains LK2-10 ${ }^{\mathrm{T}}$ and LK2-5 produced well-developed and branched substrate hyphae on ISP2 medium, but no aerial hyphae. Spores were borne singly on the substrate hyphae, and were $0.45 \mu \mathrm{m}$ in diameter. Spores had a rough and nodular surface and were non-motile. The colour of the substrate mycelium was yellowish white to dull orange (Table 1). Pale-yellow soluble pigment is produced in ISP2 and ISP3 media and in nutrient agar.

Strains LK2-10 ${ }^{\mathrm{T}}$ and LK2-5 had identical chemotaxonomic characteristics, and these were similar to those of members of the genus Micromonospora. Cell wall hydrolysates of the two strains contained glutamic acid, glycine, alanine and $\mathrm{A}_{2} \mathrm{pm}$ in a molar ratio of $1 \cdot 0: 0 \cdot 9: 0 \cdot 5: 1 \cdot 1$ (calculated by defining the amount of glutamic acid as $1 \cdot 0$ ), and the isomer of $\mathrm{A}_{2} \mathrm{pm}$ was meso, indicating that these strains have wall chemotype II of Lechevalier \& Lechevalier (1970) and peptidoglycan type Al $\gamma$ of Schleifer \& Kandler (1972). The acyl type of cell wall muramic acid was glycolyl. The strains contained glucose, xylose, arabinose, galactose, mannose and ribose as whole-cell sugars, but rhamnose was not detected (whole-cell sugar pattern D of Lechevalier \& Lechevalier, 1970). Characteristic phospholipids were diphosphatidylglycerol, phosphatidylinositol, phosphatidylinositolmannosides and phosphatidylethanolamine, but not phosphatidylcholine. This pattern corresponds to phospholipid type II of Lechevalier et al. (1977). The major cellular fatty acids of strains $\mathrm{LK} 2-10^{\mathrm{T}}$ and LK2-5 were iso- $\mathrm{C}_{15: 0}$, iso- $\mathrm{C}_{16: 0}$, iso- $\mathrm{C}_{17: 0}$, anteiso- $\mathrm{C}_{15: 0}, \mathrm{C}_{17: 0}$ and anteiso- $\mathrm{C}_{17: 0}$. This pattern corresponds to fatty acid type 3b of Kroppenstedt (1985). Mycolic acids were absent. The predominant menaquinones were MK- $9\left(\mathrm{H}_{4}\right)$, MK$10\left(\mathrm{H}_{4}\right)$ and MK-9 $\left(\mathrm{H}_{6}\right)$, and minor amounts of MK-9 $\left(\mathrm{H}_{8}\right)$, MK-10 $\left(\mathrm{H}_{6}\right)$, MK-10 $\left(\mathrm{H}_{8}\right)$ and MK-9 $\left(\mathrm{H}_{2}\right)$ were also present. The DNA G $+\mathrm{C}$ contents of strains LK2-10 ${ }^{\mathrm{T}}$ and LK2-5 were $71 \cdot 5$ and $71 \cdot 2 \mathrm{~mol} \%$.

Almost complete 16S rRNA gene sequences (1477 nt) were determined for strains LK2-10 ${ }^{\mathrm{T}}$ and LK2-5; a $1421 \mathrm{nt}$ fragment was used for phylogenetic analysis and compared against $16 \mathrm{~S}$ rRNA gene sequences of members of the family Micromonosporaceae. Phylogenetic analysis based on this large dataset revealed that strains LK2-10 ${ }^{\mathrm{T}}$ and LK2-5 were placed within the clade of the genus Micromonospora (data not shown). When the sequences of strains LK2-10 ${ }^{\mathrm{T}}$ and LK2-5 were compared with corresponding $16 \mathrm{~S}$ rRNA gene sequences of all type strains of recognized Micromonospora species, selected sequences of the genus Actinoplanes and the 16S rRNA gene sequence of Streptomyces ambofaciens (as an outgroup), they formed a clade with $M$. nigra DSM $43818^{\mathrm{T}}$ (Fig. 1). 16S rRNA gene sequence similarity values between strain LK2-10 ${ }^{\mathrm{T}}$ and all of the type strains of the genus Micromonospora ranged from $98 \cdot 1 \%$ (with M. matsumotoense IMSNU $22003^{\mathrm{T}}$ ) to $99 \cdot 1 \%$ (with $M$. nigra DSM $43818^{\mathrm{T}}$ ) and strain LK2-10 $0^{\mathrm{T}}$ showed $99 \cdot 9 \%$ sequence similarity to strain LK2-5; these similarities represent 28,14 and one nucleotide differences, respectively. On the basis of morphological, chemotaxonomic and phylogenetic data, the isolates should be classified in the genus Micromonospora.

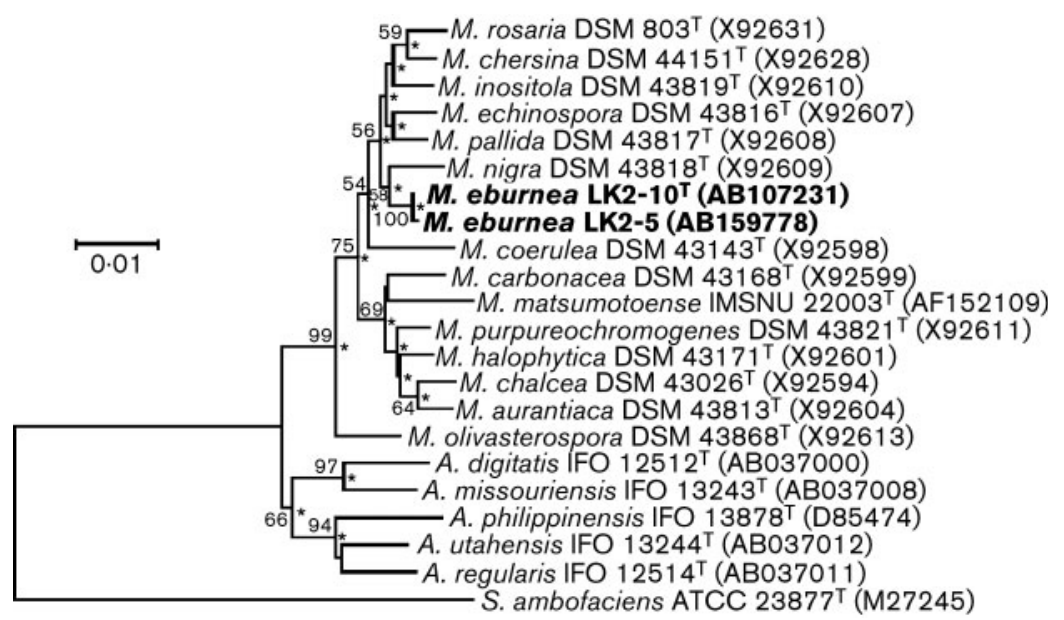

Fig. 1. Neighbour-joining tree (Saitou \& Nei, 1987) based on almost-complete $16 S$ rRNA gene sequences showing relationships among strains LK2-10 ${ }^{\top}$, LK2-5, the 14 recognized Micromonospora species and representatives of the genus Actinoplanes (A.). Streptomyces ambofaciens is used as an outgroup. Asterisks indicate branches of the tree that were also found using the maximumparsimony method (Kluge \& Farris, 1969). Numbers on branches indicate percentage bootstrap values from 1000 replicates; only values $>50 \%$ are indicated. Bar, 0.01 substitutions per nucleotide position. 
Table 2. Differential physiological and biochemical characteristics of strains LK2-10 and LK2-5 and type strains of the closest Micromonospora species

Strains: 1 , LK2-10 ${ }^{\mathrm{T}} ; 2$, LK2-5; 3, M. nigra JCM 8973 ${ }^{\mathrm{T}}$ 4, M. halophytica JCM $3125^{\mathrm{T}} ; 5$, M. aurantiaca JCM $10878^{\mathrm{T}}$. +, Positive; -, negative; W, weakly positive. All strains were positive for nitrate reduction, peptonization of milk, utilization of D-glucose, Dmelibiose, D-galactose, cellobiose and D-xylose and growth at $40{ }^{\circ} \mathrm{C}$ and in $4 \% \mathrm{NaCl}$ and negative for decomposition of adenine, hypoxanthine and xanthine and utilization of D-ribose.

\begin{tabular}{|lccccc|}
\hline Characteristic & $\mathbf{1}$ & $\mathbf{2}$ & $\mathbf{3}$ & $\mathbf{4}$ & $\mathbf{5}$ \\
\hline Gelatin liquefaction & + & + & - & $\mathrm{W}$ & + \\
Starch hydrolysis & $\mathrm{W}$ & $\mathrm{W}$ & + & + & - \\
Tyrosine decomposition & - & - & - & - & + \\
Growth at $45^{\circ} \mathrm{C}$ & + & $\mathrm{W}$ & - & - & - \\
Utilization of: & & & & & \\
D-Mannitol & $\mathrm{W}$ & $\mathrm{W}$ & - & - & - \\
L-Rhamnose & + & + & - & $\mathrm{W}$ & - \\
D-Raffinose & + & + & + & + & - \\
Glycerol & + & + & - & - & - \\
Salicin & + & + & + & + & - \\
Lactose & + & + & + & + & - \\
L-Arabinose & - & - & $\mathrm{W}$ & + & $\mathrm{W}$ \\
D-Fructose & - & - & $\mathrm{W}$ & + & + \\
\hline
\end{tabular}

The optimal temperature for growth of strains $\mathrm{LK} 2-10^{\mathrm{T}}$ and LK2-5 was $25-30^{\circ} \mathrm{C}$. No growth was observed above $45^{\circ} \mathrm{C}$. The maximum $\mathrm{NaCl}$ concentration for growth was $4 \%$, as with M. nigra JCM $8973^{\mathrm{T}}$, M. aurantiaca JCM $10878^{\mathrm{T}}$ and
M. halophytica JCM $3125^{\mathrm{T}}$. Strains LK2-10 ${ }^{\mathrm{T}}$ and LK2-5 showed almost identical physiological and biochemical properties to M. nigra JCM $8973^{\mathrm{T}}$, M. aurantiaca JCM $10878^{\mathrm{T}}$ and $M$. halophytica JCM $3125^{\mathrm{T}}$, but could be distinguished on the basis of growth at $45^{\circ} \mathrm{C}$ and utilization of D-mannitol, glycerol, L-arabinose and D-fructose. Differential characteristics between the new isolates and closely related type strains of Micromonospora species are shown in Table 2. The colour of substrate mycelium of the isolates was yellowish white, which distinguishes them from all other type strains of Micromonospora species, which generally have an orange colour. Levels of DNA-DNA relatedness between strains $\mathrm{LK} 2-10^{\mathrm{T}}$ and LK2-5 ranged from 89 to $92 \%$, whereas relatedness between the isolates and type strains of all recognized Micromonospora species except M. gallica ranged from 21 to $58 \%$ (Table 3).

These phenotypic and genotypic data indicated that strains LK2-10 ${ }^{\mathrm{T}}$ and LK2-5 belong to the same species and merit classification as a novel species of the genus Micromonospora, for which we propose the name Micromonospora eburnea sp. nov.

\section{Description of Micromonospora eburnea sp. nov.}

Micromonospora eburnea (eb.ur'ne.a. L. fem. adj. eburnea ivory, referring to colour of colonies).

Aerobic, Gram-positive, mesophilic, non-motile actinomycete that forms well-developed and branched substrate hyphae. Colonies are yellowish white and turn greyish black after sporulation in ISP2 medium. Single spores are formed on substrate hyphae. Aerial mycelium is absent. The spore

Table 3. DNA base composition and DNA-DNA relatedness among the isolates and type strains of Micromonospora species

\begin{tabular}{|c|c|c|c|}
\hline \multirow[t]{2}{*}{ Strain } & \multirow[t]{2}{*}{$\begin{array}{c}\mathrm{G}+\mathrm{C} \text { content } \\
(\mathrm{mol} \%)\end{array}$} & \multicolumn{2}{|c|}{$\begin{array}{l}\text { DNA-DNA binding (\%) } \\
\text { with labelled DNA from: }\end{array}$} \\
\hline & & LK2-10 ${ }^{\mathrm{T}}$ & LK2-5 \\
\hline LK2-10 $10^{\mathrm{T}}$ & $71 \cdot 5$ & 100 & 92 \\
\hline LK2-5 & $71 \cdot 2$ & 89 & 100 \\
\hline M. chersina JCM $9459^{\mathrm{T}}$ & $72 \cdot 9$ & 36 & 51 \\
\hline M. coerulea JCM $3175^{\mathrm{T}}$ & $71 \cdot 7$ & 26 & 40 \\
\hline M. purpureochromogenes JCM $3156^{\mathrm{T}}$ & $73 \cdot 0$ & 28 & 42 \\
\hline M. echinospora JCM $3073^{\mathrm{T}}$ & $71 \cdot 7$ & 21 & 36 \\
\hline M. carbonacea JCM $3139^{\mathrm{T}}$ & $73 \cdot 3$ & 27 & 54 \\
\hline M. chalcea JCM $3031^{\mathrm{T}}$ & $71 \cdot 9$ & 27 & 41 \\
\hline M. inositola JCM $6239^{\mathrm{T}}$ & $71 \cdot 4$ & 29 & 45 \\
\hline M. olivasterospora JCM $7348^{\mathrm{T}}$ & $71 \cdot 9$ & 24 & 38 \\
\hline M. nigra JCM $8973^{\mathrm{T}}$ & $71 \cdot 7$ & 26 & 42 \\
\hline M. halophytica JCM $3125^{\mathrm{T}}$ & $72 \cdot 5$ & 36 & 58 \\
\hline M. aurantiaca JCM $10878^{\mathrm{T}}$ & $71 \cdot 6$ & 28 & 41 \\
\hline M. rosaria $\mathrm{JCM} 3159^{\mathrm{T}}$ & $72 \cdot 9$ & 24 & 40 \\
\hline M. matsumotoense JCM $9104^{\mathrm{T}}$ & $71 \cdot 0$ & 26 & 39 \\
\hline M. pallida JCM $3133^{\mathrm{T}}$ & $71 \cdot 1$ & 28 & 45 \\
\hline
\end{tabular}


surface appears rough and nodular. Spores are non-motile. Pale yellow soluble pigment is produced in ISP2 and ISP3 media and in nutrient agar. Nitrate is reduced to nitrite. Utilizes D-glucose, L-rhamnose, D-melibiose, D-raffinose, glycerol, salicin, lactose, cellobiose and D-xylose; weakly utilizes D-mannitol and D-galactose but not L-arabinose, D-fructose or D-ribose. Peptonization of milk, hydrolysis of starch and gelatin liquefaction are positive, but formation of melanin and $\mathrm{H}_{2} \mathrm{~S}$ production are negative. Optimal temperature for growth is $25-30^{\circ} \mathrm{C}$. No growth occurs above $45^{\circ} \mathrm{C}$. The maximum $\mathrm{NaCl}$ concentration for growth is $4 \%$. Cell wall contains glutamic acid, glycine, alanine and meso- $\mathrm{A}_{2} \mathrm{pm}$ in the molar ratio $1: 0 \cdot 9: 0 \cdot 5: 1 \cdot 1$. Acyl type of the cell wall is glycolyl. The predominant menaquinone is MK-9 $\left(\mathrm{H}_{4}\right)$. Characteristic whole-cell sugars are xylose and arabinose. The phospholipid profile comprises diphosphatidylglycerol, phosphatidylinositolmannosides, phosphatidylinositol and phosphatidylethanolamine, but not phosphatidylcholine. The major fatty acids of the type strain are iso- $\mathrm{C}_{15: 0}(24 \cdot 1 \%)$, iso- $\mathrm{C}_{16: 0}(17 \cdot 9 \%)$, iso- $\mathrm{C}_{17: 0}$ $(7 \cdot 7 \%)$, anteiso- $\mathrm{C}_{15: 0}(8 \cdot 5 \%), \mathrm{C}_{17: 0}(7 \cdot 9 \%)$ and anteiso$\mathrm{C}_{17: 0}(10 \cdot 1 \%)$. The $\mathrm{G}+\mathrm{C}$ content of the DNA is $71 \cdot 5 \mathrm{~mol} \%$. Habitat is soil.

The type strain is LK2-10 $0^{\mathrm{T}}\left(=\mathrm{JCM} 12345^{\mathrm{T}}=\mathrm{PCU} 238^{\mathrm{T}}=\right.$ DSM $44814^{\mathrm{T}}=$ TISTR $1531^{\mathrm{T}}$ ).

\section{Acknowledgements}

A scholarship from the Royal Golden Jubilee $\mathrm{PhD}$ Program to C. T. is gratefully acknowledged. We thank M. Chijimatsu and H. Morishita, Research Resources Center, the RIKEN Brain Science Institute, for analysing the amino acid composition of cell wall peptidoglycan.

\section{References}

Arai, T. (1975). Culture Media for Actinomycetes. Tokyo: The Society for Actinomycetes Japan.

Collins, M. D., Pirouz, T., Goodfellow, M. \& Minnikin, D. E. (1977). Distribution of menaquinones in actinomycetes and corynebacteria. J Gen Microbiol 100, 221-230.

Ezaki, T., Hashimoto, Y. \& Yabuuchi, E. (1989). Fluorometric deoxyribonucleic acid-deoxyribonucleic acid hybridization in microdilution wells as an alternative to membrane filter hybridization in which radioisotopes are used to determine genetic relatedness among bacterial strains. Int J Syst Bacteriol 39, 224-229.

Felsenstein, J. (1985). Confidence limits on phylogenies: an approach using the bootstrap. Evolution 39, 783-791.

Gordon, R. E., Barnett, D. A., Handerhan, J. E. \& Pang, C. H.-N. (1974). Nocardia coeliaca, Nocardia autotrophica, and the nocardin strain. Int J Syst Bacteriol 24, 54-63.

Horan, A. C. \& Brodsky, B. C. (1986). Micromonospora rosaria sp. nov., nom. rev., the rosaramicin producer. Int J Syst Bacteriol 36, 478-480.

Kämpfer, P. \& Kroppenstedt, R. M. (1996). Numerical analysis of fatty acid patterns of coryneform bacteria and related taxa. Can J Microbiol 42, 989-1005.
Kasai, H., Tamura, T. \& Harayama, S. (2000). Intrageneric relationships among Micromonospora species deduced from gyrB-based phylogeny and DNA relatedness. Int J Syst Evol Microbiol 50, 127-134.

Kawamoto, I. (1989). Genus Micromonospora. In Bergey's Manual of Systematic Bacteriology, vol. 4, pp. 2442-2450. Edited by S. T. Williams, M. E. Sharpe \& J. G. Holt. Baltimore: Williams \& Wilkins.

Kawamoto, I., Oka, T. \& Nara, T. (1981). Cell wall composition of Micromonospora olivoasterospora, Micromonospora sagamiensis, and related organisms. J Bacteriol 146, 527-534.

Kawamoto, I., Yamamoto, M. \& Nara, T. (1983). Micromonospora olivasterospora sp. nov. Int J Syst Bacteriol 33, 107-112.

Kluge, A. G. \& Farris, F. S. (1969). Quantitative phyletics and the evolution of anurans. Syst Zool 18, 1-32.

Koch, C., Kroppenstedt, R. M. \& Stackebrandt, E. (1996a). Intrageneric relationships of the actinomycete genus Micromonospora. Int J Syst Bacteriol 46, 383-387.

Koch, C., Kroppenstedt, R. M., Rainey, F. A. \& Stackebrandt, E. (1996b). 16S ribosomal DNA analysis of the genera Micromonospora, Actinoplanes, Catellatospora, Catenuloplanes, Couchioplanes, Dactylosporangium, and Pilimelia and emendation of the family Micromonosporaceae. Int J Syst Bacteriol 46, 765-768.

Kroppenstedt, R. M. (1985). Fatty acid and menaquinone analysis of actinomycetes and related organisms. In Chemical Methods in Bacterial Systematics, pp. 173-199. Edited by M. Goodfellow \& D. E. Minnikin. London: Academic Press.

Lechevalier, M. P. \& Lechevalier, H. A. (1970). Chemical composition as a criterion in the classification of aerobic actinomycetes. Int $J$ Syst Bacteriol 20, 435-443.

Lechevalier, M. P., DeBièvre, C. \& Lechevalier, H. A. (1977). Chemotaxonomy of aerobic actinomycetes: phospholipid composition. Biochem Syst Ecol 5, 249-260.

Lee, S. D., Goodfellow, M. \& Hah, Y. C. (1999). A phylogenetic analysis of the genus Catellatospora based on 16S ribosomal DNA sequence, including transfer of Catellatospora matsumotoense to the genus Micromonospora as Micromonospora matsumotoense comb. nov. FEMS Microbiol Lett 178, 349-354.

Mikami, H. \& Ishida, Y. (1983). Post-column fluorometric detection of reducing sugar in high-performance liquid chromatography using arginine. Bunseki Kagaku 32, E207-E210.

Minnikin, D. E., O’Donnell, A. G., Goodfellow, M., Alderson, G., Athalye, M., Schaal, A. \& Parlett, J. H. (1984). An integrated procedure for the extraction of bacterial isoprenoid quinones and polar lipids. J Microbiol Methods 2, 233-241.

Nakajima, Y., Kitpreechavanich, V., Suzuki, K. \& Kudo, T. (1999). Microbispora corallina sp. nov., a new species of the genus Microbispora isolated from Thai soil. Int J Syst Bacteriol 49, 1761-1767.

Orskov, J. (1923). Investigations into the Morphology of the Ray Fungi. Copenhagen: Levin and Munksgaard.

Saitou, N. \& Nei, M. (1987). The neighbor-joining method: a new method for reconstructing phylogenetic trees. Mol Biol Evol 4, 406-425.

Sasser, M. (1990). Identification of bacteria by gas chromatography of cellular fatty acids. MIDI Technical Note 101. Newark, DE: MIDI.

Schleifer, K. H. \& Kandler, O. (1972). Peptidoglycan types of bacterial cell walls and their taxonomic implications. Bacteriol Rev 36, 407-477.

Shirling, E. B. \& Gottlieb, D. (1966). Methods for characterization of Streptomyces species. Int J Syst Bacteriol 16, 313-340. 
Skerman, V. B. D., McGowan, V. \& Sneath, P. H. A. (1980). Approved lists of bacterial names. Int J Syst Bacteriol 30, 225-420.

Staneck, J. L. \& Roberts, G. D. (1974). Simplified approach to identification of aerobic actinomycetes by thin-layer chromatography. Appl Microbiol 28, 226-231.

Tamaoka, J. (1994). Determination of DNA base composition. In Chemical Methods in Prokaryotic Systematics, pp. 463-470. Edited by M. Goodfellow \& A. G. O’Donnell. Chichester: Wiley.

Tamaoka, J. \& Komagata, K. (1984). Determination of DNA base composition by reversed-phase high-performance liquid chromatography. FEMS Microbiol Lett 25, 125-128.
Thompson, J. D., Gibson, T. J., Plewniak, F., Jeanmougin, F. \& Higgins, D. G. (1997). The CLUSTAL_X windows interface: flexible strategies for multiple sequence alignment aided by quality analysis tools. Nucleic Acids Res 25, 4876-4882.

Tomita, K., Hoshino, Y., Ohkusa, N., Tsuno, T. \& Miyaki, T. (1992). Micromonospora chersina sp. nov. Actinomycetologica 6, 21-28.

Uchida, K. \& Aida, K. (1984). An improved method for the glycolate test for simple identification of the acyl type of bacterial cell walls. $J$ Gen Appl Microbiol 30, 131-134.

Williams, S. T. \& Cross, T. (1971). Actinomycetes. Methods Microbiol 4, 295-334. 